\title{
DIE ROL VAN MOREEL IN DIE MILITÊRE KONFLIK
}

\author{
Lt (SAV) E.M. Meyers*
}

\begin{abstract}
Morale is a subject of divergent views, and throughout history authoritative verdicts have been made as to its role in a military conflict. Numerous generals and historians have attested to the role of morale in victory on the battlefield. Kraines contends that due to their fanaticism, and consequent high morale, the Germans and Japanese stood out as the best combatants of World War Two.
\end{abstract}

There are numerous definitions on morale, however. Writers are unanimous on the fact that an important psychological attitude must be impressed upon the soldier by his leader, if he is to operate efficiently under stressful conditions. This view is the basis of this article.

The importance of high morale, as a quality of the mind and spirit is discussed thoroughly. The concept of morale as seen by various writers, is conveyed, and attention is given to the aspects of psychological, emotional, physical and job satisfaction. The aspect of personnel training is highlighted, while the importance of good leadership, and a belief in the cause that is being fought for is also stressed.

\begin{abstract}
Inleiding
Moreel is ' $n$ onderwerp van uiteenlopende standpunte. Gesaghebbende uitsprake dwarsdeur die geskiedenis is al oor die aandeel hiervan in die militêre konflik gemaak. Die rol van moreel in die oorwinning op die slagveld is deur talle veldhere en geskiedskrywers bevestig. Kraines beweer byvoorbeeld dat die Duitsers en Japannese as die beste vegters in die Tweede Wêreldoorlog uitstaan, omdat hulle so fanaties was hulle moreel was dus besonder hoog. ${ }^{1}$
\end{abstract}

Hoewel definisies oor moreel talryk en uiteenlopend is, is skrywers dit eens dat sonder 'n belangrike geesteshouding wat hoofsaaklik deur leiers by die soldaat ingeskep moet word, hy moeilik spanningsituasies kan hanteer. Die benadering dien as uitgangspunt in hierdie artikel.

Vervolgens word die belangrikheid van hoë moreel as eienskap van die soldaat bespreek. Baynes noem dit die kwaliteit van die verstand en gees wat moed, selfdissipline en lydsaamheid verenig. ${ }^{2}$ Hierteenoor word swak moreel geskep wanneer die soldaat deur sy eie gedagtes verslaan is, aldus Lord Moran. ${ }^{3}$ Laastens word algemene beskouings ivm die verskil tussen moreel en dissipline weergegee. Die geheim wat die verskil tussen die gevegsoldaat en die opgeleide robot bepaal, is volgens Kraines die basiese oortuiging dat jy reg is. ${ }^{4}$

Die begrip word tot in die fynste nuanse in die tweede afdeling ontleed aan die hand van etlike taalkundige verklarings. Die verwarring tussen die begrippe moreel en moraal word aan die lig gebring en 'n ontleding van die begrip moreel, soos deur verskeie skrywers vertolk, word weergegee. Aspekte van moreel waaraan aandag gegee word, is die geestelike, emosionele en fisiese asook werkbevrediging. ' $n$ Verdere faset wat uitgelig word, behels die opleiding van personeel.

By die bespreking van die opbou van moreel in die laaste afdeling word die aandeel van goeie leierskap, die noodsaak vir die soldaat om te glo waarvoor hy veg en om vertroue in die saak te hê, uitgelig. Ten slotte word die rol van moreelopbouers soos materiële geriewe, goed georganiseerde logistiek, deeglike administrasie, groepskohesie en selfvertroue van nader beskou.

\section{Standpunte en beskouinge}

Moreel is al deur verskeie veldhere en militêre strateë bestempel as die belangrikste eienskap waaroor 'n vegtende soldaat moet beskik. Napoleon het byvoorbeeld gesê dat moreel vyf en sewentig persent uitmaak van al die elemente waaruit gevegseffektiwiteit bestaan of anders gestel, dat moreel in verhouding tot materieel gelyk is aan drie tot een. Lejeune beweer dat Napoleon met sy stelling die gedagte wou oordra dat 'n leër met 'n hoë moreel en 'n goeie 
veggees enige leër met 'n lae moreel en 'n swak gees wat drie keer talryker is, kan verslaan. ${ }^{5}$

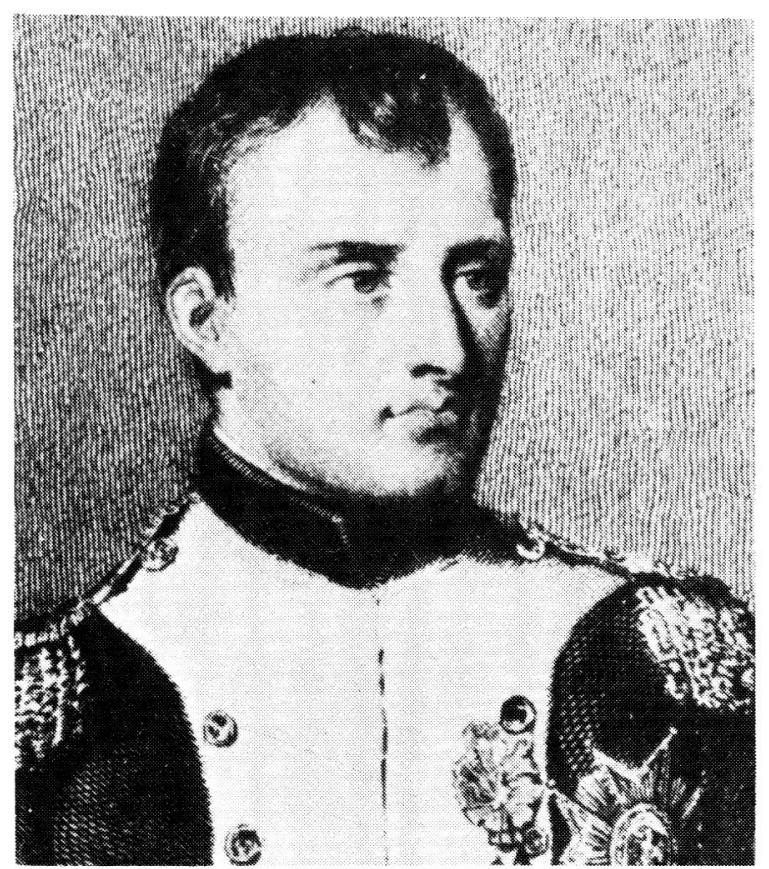

Die Franse veldheer Napoleon Bonaparte wat deur sy besielende leierskap en charisma 'n hoë moreel by sy soldate ingeboesem het

Vir die militêre strateeg, Von Clausewitz, was dit allerbelangrik dat ' $n$ vegtende soldaat nie deur die onbekende oorval moet word nie. Hy het dit as volg opgesom: 'It - is of the first importance that the soldier high or low should not have to encounter in war things which seen for the first time set him in terror or perplexity. ${ }^{6}$

Veldmaarskalk Montgomery het moreel beskou as ' $n$ deurlopende vasberadenheid van 'n groep om ' $n$ vooropgestelde doel te verwesenlik. ${ }^{7}$ Die skrywer van The Anatomy of Courage, Lord Moran, verklaar in dieselfde verband: 'It is not the number of soldiers but their will to win that decides battles. ${ }^{8}$

Uit eie bodem het generaal De Wet in Maart 1900 verklaar dat tien man wat gewillig is om te veg wensliker was as honderd wat hulle pligte ontwyk het. Minder as drie weke na die val van Bloemfontein het hy met skaars 1500 man op die flank van die Britse leër van 30000 geopereer. $^{9}$

\section{Geesteshouding}

Lord Moran beweer dat die geheim van die Duitse leër nie tenks en vliegtuie was nie, maar 'n sekere geesteshouding van sy manlike bevol- king, 'n trots om gekies te wees as soldaat van die vaderland. Die Duitse soldaat is deur homself en deur die nasie as lid van 'n bevoorregte burgerskap beskou. ${ }^{10}$

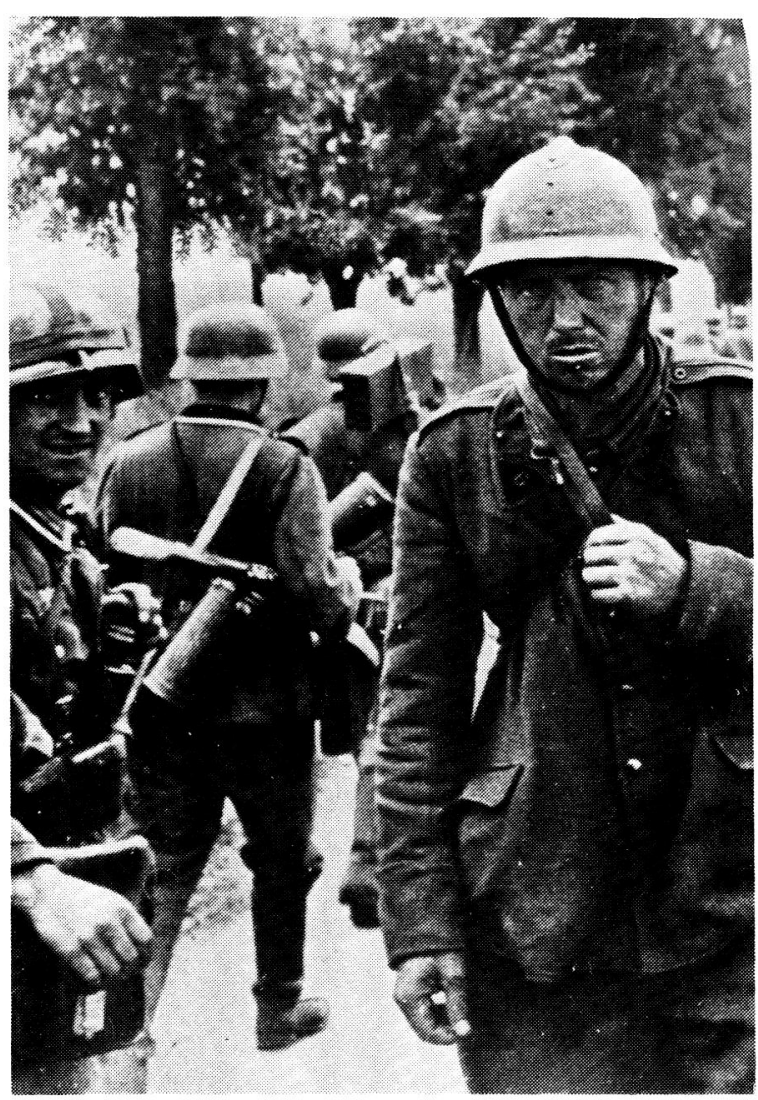

Duitse soldate en 'n Franse krygsgevangene tydens 'n veldslag in die Tweede Wêreldoorlog. Faktore soos 'n effektiewe propagandamasjien, deeglike militêre skoling en totale volksbetrokkenheid het 'n hoë moreel by die Duitse soldaat ingeskerp

Wanneer die stryd verlang word, aldus Copeland, is dit morele krag en nie fisiese vermoë nie, wat dit oor die algmeen besleg. Hy beweer dat 'n leër nooit verslaan is totdat dit sy neerlaag besef nie, want neerlaag is ' $n$ geesteshouding en nie 'n fisiese toestand nie. ${ }^{11}$

Baynes haal Lord Moran aan wat aanvoer dat 'a man's will to fight is the ultimate arbiter of battles and that this is governed by thoughts however elementary which pass through his head. ${ }^{12}$ Dollard en Horton brei hierop uit in hulle definisie van moreel. Hulle meen dat vrees versmelt met honger en uitputting neig om manne uit die geveg te dryf. Ander sterker magte moet teen vrees opgestel word om die manne daarin te dryf. Die nettobalans is moreel. ${ }^{13}$

Pakenham noem in sy werk The Boer War dat pres Steyn die rol van Kruger oorgeneem het as profeet van die volk. Ten spyte van grootskaalse 
ALLIED FORCE HEADOUARTEKS Aptil, 1945

\section{SPECIAL ORDER OF THE DAY}

Soldiers, Sailors and Airmen of the Allied Forces in the Mediterranean Theatre

Final victory is near. The German Forces are now very groggy and only need one mighty punch to knock them out for good. The moment has now come for us to take the field for the last battle which will end the war in Europe. You know what our comrades in the West and in the East are doing on the battlefields. It is now our turn to play our decisive part. It will not be a walk-over; a mortally wounded beast can still be very dangerous. You must be prepared for a hard and bitter fight: but the end is quite certain - there is not the slightest shadow of doubt about that. You, who bave won every battle you have fought, are going to wir this last one.

Forward then into batile with confidence, faikh and detemination to see it throngh to the end. Condspeed and good luck to you all

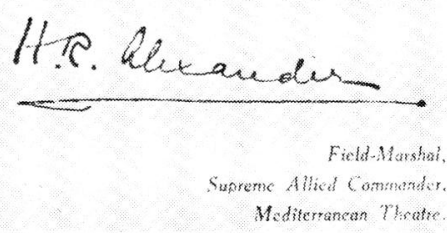

'n Spesiale order wat deur die Geallieerde hoofkwartier teen die einde van die Tweede Wêreldoorlog uitgereik is om die Geallieerde magte tot die finale oorwinning aan te spoor. Dié order was egter oorbodig want die moreel van die Geallieerde magte was in daardie stadium op sy hoogste

oorgawe van burgers sedert die val van Bloemfontein het Steyn en De Wet nooit in hulle afkeer vir vredesonderhandelinge getwyfel nie. ${ }^{19}$

\section{Groepskohesie}

Wat groepsaambinding betref, is Trotter se teorie wat die mens as kuddedier definieer, insiggewend. As sodanig voel die mens gelukkig, veilig en bekwaam wanneer hy met sy medemens in aanraking is. Morele ondersteuning kan slegs bekom word deur by die kudde aan te sluit. Daar bestaan geen konflik meer tussen individuele en groepsstandaarde nie: die mens word 'n ongedifferensieerde eenheid en gaan in die groep op. ${ }^{14}$ Moreel wat ooglopend goed, of skreiend sleg is, dui op ' $n$ eensgesindheid van handeling in die groep wat 'n dapperheid of lafhartigheid weerspieël. ${ }^{15}$

Moreel kan as hoog beskou word as 'n groep individue bymekaargehou word deur interne groepsgebondenheid eerder as eksterne druk. Lede met ' $n$ hoë moreel aanvaar ' $n$ gemeenskaplike doel waaraan hulle eie belange ondergeskik gestel word en werk na die gemeenskaplike doel. Hoë moreel in groepsverband behels verder die vermoë van die groep om hom aan te pas by veranderende omstandighede en die begeerte van die lede om in die groep te bly en die hoogste bydrae tot die groep te lewer. ${ }^{16}$

\section{Leiers}

Die aandeel van leiers in die opbou van moreel word allerweë beklemtoon. Kraines verklaar onomwonde dat 'the basic mental health and morale of a soldier is influenced primarily by its leaders'. ${ }^{17}$

In sy telegramme tydens die Tweede Vryheidsoorlog na die slagveld het pres Kruger die Boere keer op keer aangevuur om die stryd teen die Engelse voort te sit. Nadat generaal Botha op 13 Desember 1899 deur die Britte by Boschkop aangeval is, het pres Kruger twee telegramme aan Botha en sy volgelinge gestuur waarin hy hulle gewaarsku het dat as hulle hul posisies sou opgee, hulle hul land ook aan die vyand sou oorgee. 'Staan vas, dood of lewendig in die naam van die Here. ${ }^{18}$

\section{Goeie Moreel}

Grinker en Spiegel definieer goeie moreel as 'n toestand waarin manne selfvertroue het en as sodanig tevrede, verenig en gretig is om te veg. $^{20}$

Hoë moreel, aldus Baynes, was in 1915 by die Britse frontlinie-soldaat aanwesig. Sy werk was om die Duitsers te verslaan en hy het homself nie tyd gegun om nabetragting oor sy dade te hou nie. Hy het 'n oorwinning oor die Duitsers deur sy eie bataljon gevisualiseer. ${ }^{21}$

Railey definieer hoë moreel as die 'cheerful, willing and obedient performance of the most arduous duties under the most adverse circumstances. ${ }^{.22}$ Sophia du Preez noem dat die stelsel van 'n nasionale leër dit vir die republikeinse regerings in die tweede Vryheidsoorlog moontlik gemaak het om die stryd met besielde manskappe te voer ondanks baie ontberings en gebrek. ${ }^{23}$

\section{Swak Moreel}

Swak moreel impliseer dat manne moedeloos, ongeorganiseerd en sku is vir die geveg. ${ }^{24} \mathrm{Om}$ onnodige ongevalle te ly, dui op 'n lae moreel. 


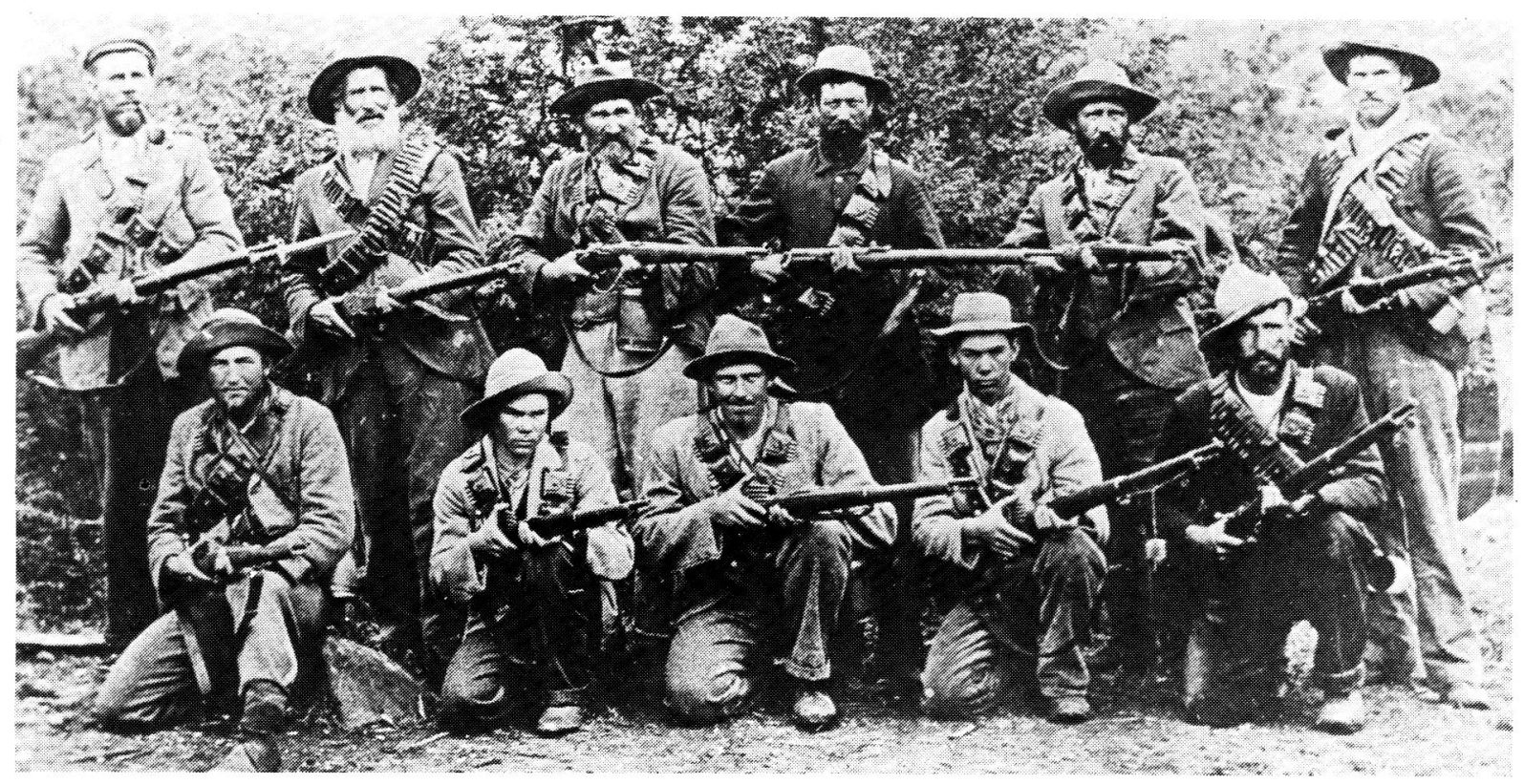

'n Groep Boerekrygers te velde in die Tweede Vryheidsoorlog. Ondanks die felle invloed van eksterne fisiese faktore op die Boeremagte se moreel, kon hulle drie jaar lank die stryd volhou en selfs teen die einde was daar baie wat bereid was om voort te veg

Die finale toets vir moreel aldus Baynes, is of jy bereid is om jouself op te offer ${ }^{25}$ Railey het in sy verslag die moreelkrisis van die Amerikaners in 1941 aan nasionale onsekerheid toegeskryf. Hy stel dit dat as die Amerikaanse politieke leiers 'n militêre doelstelling gehad het, hulle dit nie aan die leër verduidelik het nie. ${ }^{26}$

Gedurende die tweede Wêreldoorlog het dit spoedig duidelik geword dat die moreel van die Italiaanse soldate baie swak was, aangesien hulle nie wou veg nie. Die optrede van krygsgevangenes bewys dit. In vergelyking met die Duitsers wat tot die einde van die oorlog goed opgepas moes word, het die Italianers probeer ontsnap en die indruk gegee dat hulle bly was om uit die geveg uit te wees. ${ }^{27}$ Dit kan verduidelik word deur die vereniging van Italië wat die kragtige anneksasie van die Pouslike State ingesluit het. Dis deur die kerk teengestaan. As volk wat hul godsdiens ernstig opgeneem het, het die Italianers dus geweier om deel te hê aan sake van die staat. ${ }^{28}$ Hulle was glad nie gretig om die risiko te neem om te sterf terwyl hulle vir die staat veg nie. Dit het op ' $n$ lae moreel gedui. ${ }^{29}$

Fisiese faktore wat bepalend is vir lae moreel, is fisiese uitputting, honger, siekte, dors en spanning as gevolg van klimaatstoestande wat die fisiese toestand van die soldate in so 'n mate kan aftakel dat sy wil om te veg, gebreek word. ${ }^{30} \mathrm{Op}$ eie bodem was die moreel van die Britse troepe na die slag van Modderspruit gedurende die Tweede Vryheidsoorlog geskud. Tog kon gene- raal Joubert dit nie agterkom nie. Die krag van sy eie troepe het gekwyn, omdat hulle bang was dat die Britse troepe uit die lokval by Ladysmith sou ontsnap en die Boere het gevolglik huis toe begin dros. In wanhoop het Joubert na Kruger in Pretoria getelegrafeer dat die saak op niks sou uitloop as die regering hom geen steun kon gee nie. Joubert het versoek dat Kruger ' $n$ regeringsorder moes uitvaardig om die afwesige burgers dadelik terug te stuur, anders sou daar kort voor lank geen kommando's meer wees nie. ${ }^{31}$ Dit is 'n goeie illustrasie van lae moreel.

\section{Dissipline - Moreel}

Voordat algemene beskouinge ter syde gelaat word, moet op die verskil tussen moreel en dissipline gelet word. Bartlett beskou moreel in dié sin dat dit 'n gematigder, meer aanhoudende, minder wisselende soort gedrag tot gevolg het as dissipline. Moreel kan voortgaan wanneer al die uiterlike elemente van bevel en beheer verbrokkel het. ${ }^{32}$

In sy vergelyking van dissipline met moreel voer Lord Moran aan dat ' $n$ gedissiplineerde man iets doen op die aansporing van iemand anders - as hy dit nie doen nie, word hy gestraf. ' $n$ Man met 'n hoë moreel doen dinge omdat hy vir homself besluit het om dit te doen sonder enige voorstel of druk van eksterne faktore. Dissipline aan die ander kant, die beheer van buite, kan net verslap word as dit deur iets hoër en beter vervang word, te wete innerlike beheer ${ }^{33}$ Lord Moran gaan ver- 
der en beskryf moreel as die selfdissipline wat ' $n$ man tot die bemeestering van sy kuns toe dryf deur die lang vervelige dae waarin hy plesier moet ontbeer ${ }^{34}$

\section{Ontleding van die begrip moreel}

\section{Taalkundige Ontledings}

By ontleding en definisie van moreel is dit opvallend dat daar 'n groot mate van verwarring heers betreffende die begrippe 'moreel' en 'moraal'. Dit word verder bemoeilik aangesien die man op straat die begrippe anders verstaan as wat dit in die militêre opset vertolk word. Die algemene publiek is geneig om te glo dat moraal verwys na die vlak van gemotiveerdheid van 'n persoon, na sy vermoë om ten spyte van terugslae of ontbering, 'n gees van optimisme te behou. (sic). Moreel word oor die algemeen met die mens se sedelike lewe in verband gebring, dit behels wat die mense as goed of sleg beskou (sic) ${ }^{35}$

Volgens die Verklarende Handwoordeboek van die Afrikaanse Taal (HAT) is die algemene gebruik van moraal en moreel foutief. Die HAT verduidelik die twee begrippe as volg:

Moraal: 1. Sedeleer; 2. Voorstelling van wat goed of sleg is; sedelike beginsels. 3 . Sedeles, sedelike strekking.

Moreel: 1. Sedelike en geestelike krag wat mense vol moed en geesdrif laat bly veral gebruik ivm soldate soos getoon deur hulle tug, gewilligheid om gevare die hoof te bied, ens. 2. Wat betrekking het op die gevoel vir wat goed of reg is; sedelik. ${ }^{36}$

Die Verklarende Afrikaanse Woordeboek van Kritzinger en Labuschagne omskryf moreel in ' $n$ meer militêre verband: 'Moreel - dissipline, bewustheid van dissipline gevoel van innerlike waarde. $^{37}$

Hierdie gelykstelling van moreel en dissipline is soos die opstellers self aandui, slegs in 'n algemene verband. In die militêre konteks is moreel en dissipline sowel as esprit de corps nie sinnoniem nie, alhoewel daar tog 'n sterk onderlinge verband is. Moreel is 'n oorkoepelende faktor waarvan esprit de corps en dissipline slegs onderdele is. ${ }^{38}$

Die Concise Oxford Dictionary definieer moreel as die 'moral condition especially of troops as regards discipline and confidence'. Moraal is hiervolgens 'concerned with character or disposition between right and wrong. ${ }^{39}$

Die militêre betekenis van moreel word beskryf in die Gesamentlike Operasionele Woordeboek (SAW). 'Moreel is dissipline, veggees, selfvertroue en die hele geestestoestand van ' $n$ man, vrou of eenheid waaraan sy of haar wil om ten alle koste te wen, gemeet kan word. Hoë moreel is noodsaaklik om te wen terwyl swak moreel op 'n neerlaag sal uitloop. ${ }^{40}$

\section{Ander Ontledings}

By die verdere ontleding van die begrip moreel is daar vele skrywers wat al gepoog het om 'n korrekte omskrywing, ontleding en verduideliking van moreel te gee. Deursettingsvermoë gegrond op 'n positiewe geestestoestand vorm die kern van baie verklarings.

Op die breedste gesien, word moreel beskou as die manier waarop mense reageer op hul lewenstoestande. Dit word dikwels toegepas op aspekte van die lewe wat moeilik en gevaarlik is en het dikwels militêre konotasies. ${ }^{41}$

\section{Geestelike Aspek}

Copeland beklemtoon die geestelike aspek van moreel. Dis nie net 'n fisiese of verstandelike toestand nie, maar bestaan uit veggees, dissipline, die wil om te wen, selfbeheersing, selfrespek, lojaliteit en ' $n$ besondere eergevoeligheid. ${ }^{42}$

\section{Emosionele Aspek}

Afgesien van die geestelike aspek is moreel ook al met die denk van die soldaat in verband gebring. In dié verband benadruk Baynes merendeels emosionele eienskappe soos liefde vir 'n saak en liefde vir jou land. ${ }^{43}$

Lejeune onderskryf die sienswyse dat dit die belangrikste ding is om manne te laat voel hulle is gedug en dat geen mag hulle kan verslaan nie. Die sukses van hul land se saak is van hulle organisasie afhanklik. ${ }^{44}$ Die verval van godsdiens wat al vir etlike eeue aan die gang is, word teenoor die opkoms van nasionalisme gestel. Aanbidding deur die massa in die verlede kan nou gelykgestel word aan lojaliteit aan die volk. Lejeune gebruik Naziisme en Kommunisme as voorbeelde van 'volksgodsdienste'. ${ }^{45}$

\section{Fisiese Aspekte}

Fisiese aspekte speel 'n belangrike rol by die 
bepaling van moreel se bestanddele. Oor die afgelope 60 jaar het die Amerikaanse leër moreel al hoe meer in terme van fisiese gerief en welsyn gedefinieer. In die artikel 'Determination in Battle' van Hart word fisiese uitputting, honger siekte, dors en spanning weens swak klimaatstoestande as redes aangegee wat die soldaat se fisiese toestand so kan aftakel dat sy wil om te veg, kan breek. As die effek van klimaat geneem word, kan net gekyk word na die invloed van die koue op Napoleon se leër in Rusland. ${ }^{46}$ Fisiese faktore soos byvoorbeeld die gebrek aan voldoende ammunisie, kleding en voedsel het 'n demoraliserende uitwerking op Boerekrygers in die Tweede Vryheidsoorlog gehad.

\section{Werksbevrediging}

In die jongste tyd is daar ook ' $\mathrm{n}$ tendens om moreel in terme van werksbevrediging te definieer. Dit is waarskynlik toe te skryf aan die opbloei in navorsing op die gebied van gedragswetenskappe asook die toenemende invloed op besigheidsbestuursbeginsels in die militêre sfeer. Dié standpunt word toegelig deur Paul B. Nelson wat beweer dat as die motivering, belangstelling, voorkeure en afkeure van die ervare gevegssoldaat bekend is, ' $n$ mens beter in staat sal wees om werksbevrediging van elke individu te bestudeer. Hy gaan verder deur te veronderstel dat as elke individu se vlak van werksbevrediging verbeter, die verhoging van die groep se moreel nie moeilik sal wees nie. ${ }^{47}$

\section{Opleiding}

Die professionele faset van moreel behels die opleiding van personeel. 'n Hoë mate van vaardigheid en afgerondheid bou selfvertroue wat lei tot ' $n$ hoë moreel. Goeie wapens en 'n kennis van taktiek gee ' $n$ besliste voorsprong aan die soldaat, aldus Lejeune. ${ }^{48}$

Die Grieke het geglo dat die gemeenskaplike vertroue van professionele soldate die eerste bron van krag in 'n oorlog was. ${ }^{49}$ Die welslae van die Israelimagte in konflikte in die Midde-Ooste (1956, 1967 en 1973) was tot 'n groot hoogte die gevolge van professionele opleiding.

\section{Opbou van Moreel}

By 'n studie van moreel is die vraag oor watter werkswyse gevolg moet word om moreel op te bou, toepaslik. Hierdie vraag onderstreep die aspek van moreel wat veral belangrik is vir die leier. Slegs enkele faktore kan in dié verband as riglyne dien.

\section{Positiewe Leierskap}

Dit is eerstens belangrik om daarop te let dat wanneer die moreel van die individu of die groep opgebou moet word, die opbouing van moreel by die leiers kan begin. Dit is veral die voorbeeld wat die leier stel en die vertroue wat hy by die groep inboesem, wat moreel laat styg.

Pres Steyn en generaal De Wet kan as moreelbouers by uitnemendheid beskou word. Ten spyte van grootskaalse oorgawe van burgers sedert die val van Bloemfontein, het Steyn en De Wet steeds geglo dat die stryd voortgesit moes word. Hulle sou tot die bitter einde veg om die onafhanklikheid te behou. Hoewel meeste Transvaalse leiers 'n kompromie voorgestaan het, het die Transvalers se moreel herstel en hulle is tot Steyn se denkwyse oorgehaal om die geveg voort te sit. ${ }^{50}$

Die National Research Council het bevind dat moreelbou 'n primêre taak van leierskap is. 'n Leier moet nooit ' $n$ man laat vergeet dat hy ' $n$ soldaat is nie en dat die eenheid ' $n$ funksie het, $\mathrm{nl}$ om die oorlog te wen. ${ }^{51}$

' $n$ Leier moet met sy mense meng, hulle vertroue wen en weet wat hulle dink en sê. Hy moet dit by hulle tuisbring dat hy persoonlik in hulle belangstel. Hy moet hulle ingelig hou en op hoogte bly met hulle denke en gevoelens. Die leier moet poog om sy manne positief te begeester. ${ }^{52}$ Wanneer ' $n$ man bang is in die ware geveg, aldus Kraines, is aanmoediging van ' $n$ leier meer effektief as vrees om hom tot beweging aan te spoor. ${ }^{53}$

\section{Geloof in die Saak}

Manne wat beweer dat geen twyfel by hulle bestaan het of die oorlog die moeite werd was om te veg nie, se persoonlike aanpassing was gunstiger as dié van die ander. Hulle het verstaan waarom hulle veg. ${ }^{54}$

Thomas M. Camfield wys op die probleem van die moderne kerneeu om individue moreel te bearbei as hulle morele gewete in opstand kom teen die bestek van vernietiging.

'n Britse soldaat vertel die staaltjie hoe die Boere tydens die Tweede Vryheidsoorlog begin Psalms sing het as moreelbouer, aangesien hulle godsdiens soveel vir hulle beteken het. Die Boere het geweet waarom hulle veg en vir hulle was die saak alles, aldus Pakenham. ${ }^{56}$ 
In dieselfde trant beweer Sophia du Preez dat 'n verwoeste plaas van 'n burger dikwels 'n meer vasberade kryger van hom gemaak het. Daarbenewens het die feit dat hy uit Suid-Afrika weggestuur word as hy gevange geneem sou word, 'n belangrike rol gespeel in die positiewe prooorlogse motivering van die burgers. ${ }^{57}$

\section{Fisiese versorging, administrasie en uitrusting}

Materiële geriewe soos goeie kos en mediese versorging, deeglike administrasie soos gereelde pos, welsynsdienste en hulp aan gesinne asook goed georganiseerde logistiek soos deeglike uitrusting en wapens is belangrike moreelopbouers ${ }^{58}$ In dié verband word sukses en oorwinning ook genoem. ${ }^{59}$ Opleiding en die kweek van esprit de corps ontwikkel verder goeie moreel. ${ }^{60}$ Stouffer beklemtoon dit dat die begeerte om te oorleef meer basies is as die begeerte om huis toe te gaan en in die konteks van die bespreking kan oorlewing dus ook as 'n moreelbouer beskou word. ${ }^{61}$

Bartlett beweer dat dit belangrik is om te onthou dat in die opbou van militêre moreel alle vorms van spel mededingend moet wees. ${ }^{62}$ Dril as vredesopleiding is belangrik omdat dit ' $n$ gevoel van samehorigheid by troepe teweegbring. ${ }^{63}$

\section{Sosiale Dryfvere}

\section{a. Groepskohesie}

Wanneer primitiewe behoeftes nie langer genoeg is nie, is dit die sosiale prikkels of dryfvere wat die vegtende man help om sy beste te lewer. ${ }^{64}$ Groepskohesie as moreelbouende faktor moet nooit onderskat word nie want vrees vir ' $n$ ander se afkeur is goeie aansporing. ${ }^{65}$

Stouffer gee die voorbeeld dat die manskap se besorgdheid om die respek van sy makkers te wen, impliseer dat manskappe in enige situasie waarin daar konflik is tussen die offisiere en die groep, sal neig om met die groep en nie met die offisiere te identifiseer nie. ${ }^{66}$

Verslae oor die Viëtnam-oorlog dui daarop dat ofskoon soldate nie geweet het waarom hulle in Viëtnam moes veg nie, hulle hard geveg en groot gevare getrotseer het ter wille van hulle makkers. ${ }^{67}$

\section{b. Selfvertroue}

Dié redenasie kan afgesluit word met Copeland se stelling dat daar geen behoorlike moreel kon wees waar selfvertroue ontbreek nie. 'n Goed opgeleide, goed toegeruste soldaat sal moreel sowel as fisies superieur tot ' $n$ swak opgeleide, swak toegeruste teenstander voel. ${ }^{68}$

\section{Toekomsblik}

Oor die toekomstige rol van moreel in enige militêre bestel kan min twyfel bestaan. Hiervan getuig die feit dat die moreel van Amerikaanse soldate in Viëtnam nadelig geraak is deur verskeie faktore, onder meer ' $n$ negatiewe openbare mening, afsydige media en onsekerheid oor hul teenwoordigheid in ' $n$ vreemde land. Kennisname van dié faktore kan dien as grondslag vir enige toekomsblik oor die rol van moreel in die militêre konflik.

Eerstens moet kennis geneem word van die feit dat volksmoreel (met betrekking tot die konflik) in die moreel van die militêr gereflekteer word. Daarom kan aangeneem word dat militêre moreel nie alleen in die militêre situasie opgewek word nie, maar dat die potensiële dryfvere reeds in die gemeenskap bestaan. Meningsvormers (politici, kerklikes, opvoedkundiges, onderwysers, akademici, sakeleiers ens) kan 'n belangrike positiewe bydrae lewer tot die bevordering van moreel in die militêre organisasie.

Daarteenoor kan sodanige dryfvere ook 'n nadelige uitwerking hê. Strateë en politieke waarnemers verwys in die huidige era veelal na die fenomenale magsopbou van die Sowjet-Unie en sy vennote in die Warskouverdrag - terselfdertyd word kommer uitgespreek oor die kwynende paraatheid van die Navomagte. Maar hoe vertolk die leek hierdie vergelyking? Die vraag kan gestel word of ' $n$ gunstige oorsig van die besondere kwaliteite van die Russiese soldaat wat as uiters gedug voorgestel word, nie 'n gevoel van défaitisme by sy eweknie in die Navomagte opwek nie. In hierdie verband kan gewys word op die feit dat die moreel van Russiese soldate wat dienstermyne in lande soos Oos-Duitsland en Pole het, uiters laag is. In sy boek, Inside the KGB (1981), wys Aleksei Myagkov op 'n interessante anomalie: hoewel al die manifestasies van 'n lae moreel teenwoordig is (korrupsie, bedrog, finansiële wanpraktyke, diskriminasie en drostery), word die uiterlike beeld van militêre paraatheid slegs gehandhaaf danksy ystere dissipline, die vrees vir strafmaatreëls en die positiewe gesindheid van die openbare dryfvere: kommunistiese meningsvormers en media word nie toege- 
laat om die moreel in die gevegsmagte nadelig te beïnvloed nie.

Die Westerse soldaat, wat heelwat meer vryhede as sy eweknie in die Sowjet-Unie geniet (ook wat politieke denke betref!), sal uiteraard besin oor sy deelname aan 'n gewapende konflik, veral as dit op vreemde grondgebied gevoer word. Soos aangetoon, was Amerikaanse soldate in Viëtnam nooit behoorlik ingelig oor die redes vir Amerikaanse betrokkenheid in Viëtnam nie. Dit is derhalwe noodsaaklik dat die militêr goed ingelig en voorgelig sal word oor sy optrede. In die lig hiervan is dit begryplik dat die moreel van Russiese soldate wat hulle in Afganistan as deel van 'n besettingsmag aldaar bevind, na bewering laag is. Daarteenoor is die moreel van die Afgaanse vryheidsvegters besonder hoog want hulle weet hoekom hulle veg - 'n toedrag van sake wat enigsins aan die vryheidstryd van die Boere-republieke in die Tweede Vryheidsoorlog herinner.

Ten slotte kan die toekomstige rol van fisiese faktore in die opbou van moreel in die militêre organisasie nie genoeg beklemtoon word nie. In die voorafgaande gedeelte is historiese voorbeelde aangehaal om die belangrikheid hiervan uit te wys. Eerstens moet aanvaar word dat die invloed van fisiese omgewingsfaktore op moreel ook deur die militêr se kulturele agtergrond bepaal word - ofskoon Britse soldate in die Tweede Wêreldoorlog in terme van soldy, uitrusting en diensvoordele nie so goed daaraan toe was as hul Amerikaanse bondgenote nie, is hul moreel nie daardeur beïnvloed nie. In die toekoms sal die weermagte van die wêreld meer aandag aan die materiële aspekte van diensplig moet skenk.

*Lt. (SAV) E.M. Meyers, MA HOD is verbonde aan die Militêre Informasieburo van die SAW

\section{Verwysings}

1. Kraines, S.H., Managing Man, Preventive Psychiatry, A.B. Hirschfield Press, Denver, 1964, p 70

2. Baynes, John, Morale. A study of Men and Courage, Cassell, London, 1967, p 108

3. Moran, Lord, The Anatomy of Courage, Constable, London, 1966, p 101

4. Kraines, op cit, $p 73$

5. Lejeune, John A, "A Legacy of esprit and leadership", Marine Corps Gazette, vol 13, no 7, July 1979, p 33

6. Hart, T.S., "Determination in Battle", Armour, vol 59, no 3, May - June 1980, p 31

7. Adiseshiah, W.T.V., "Human Relations in Military Societies", Military Review, vol 40, no 8, Nov 1960, p 95

8. Moran op cit, $p 92$

9. Pakenham, Thomas, The Boer War, Mac Donald and Co, London and Sydney, 1982, p 387

10. Moran, op cit, $\mathrm{p} 172$

11. Copeland, Norman, Psychology and the Soldier, The Military Service Publishing Company Harrisburg, Pensylvania. $p$ i3
12. Moran, op cit, p 92

13. Dollard, J. en Horton, D., Fear in Battle, Greenwood Press Publishers, Westport, Connecticut, 1900, p 38

14. Mac Curdy, J.T., The Structure of Morale, Cambridge University press, London, 1943, p 59

15. Ibid, $p 62$

16. Adiseshiah, op cit, p 95

17. Kraines, op cit, $p 3$

18. Pakenham, op cit, p 471.

19. Ibid

20. Grinker, Roy en Spiegel, John P., Men under Stress, Mc Graw-Hill Book Co. Inc., New York, 1963, p 37

21. Baynes, op cit, p 88

22. Wesbrook, S.D., "The Railey Report and Army Morale, 1941: Anatomy of a Crisis", Military Review, Vol 40, no 6, p 17

23. Du Preez, Sophia, Vredespogings gedurende die Anglo-Boereoorlog tot Maart 1901, M.A.-Theses, U.P., 1976, p 56

24. Grinker en Spiegel, op cit, p 37

25. Baynes, op cit, $p 97$

26. Wesbrook, op cit, p 14

27. Andreski, Stanislav, "Italian Military Efficiency: A Debate. Causes of the Low Morale of the Italian Armed Forces in the Two World Wars", Journal of Strategic Studies, vol 5, no 2, Jun 1982, p 249

28. Ibid, p 253

29. Ibid.

30. Hart, op cit, p 32

31. Pakenham, op cit, $p 170$

32. Bartlett, F.C., Psychology and the Soldier, Cambridge University Press, London, 1927, p 157

33. Moran, op cit, p 166

34.Ibid, p 173

35. Rigtingwyser no 16, 1980, "Faktore wat moreel in die Militêre Situasie Beïnvloed: Standpunte en Beskouinge", p 4

36. Odendaal, F.F., ea reds, Verkiarende Handwoordeboek van die Afrikaanse Taal, Perskor, Johannesburg, 1979, p 713

37. Kritzinger, ea, Verklarende Afrikaanse Woordeboek, Pretoria, 1980, p 622

38. Rigtingwyser no 16 , op cit, p 5

39. Baynes, op cit, $p 92$

40. Rigtingwyser no 16 , op cit, p 5

41. Baynes, op cit, $\mathrm{p} 92$

42. Copeland, op cit, $p 8$

43. Baynes, op cit, pp 97,98

44. Lejeune, op cit, $p 37$

45. Mac Curdy, op cit, op 120, 121

46. Hart, op cit, p 32

47. Nelson, P.B., "The Morale of the Individual Soldier", Australian Army Journal, no 54, Nov 1953, pp 32, 33 en 38

48. Lejeune, op cit, $p 13$

49. Moran, op cit, p 170

50. Pakenham, op cit, pp 471, 472

51. National Research Council, Psychology for the Fighting Man, The Infantry Journal, Washington, 1943, p 291

52. Lejeune, op cit, $p$ 35; Wesbrook, op cit, $p 22$

53. Kraines, op cit. p 158; Baynes, op cit, p 98

54. Stouffer, S.A., ea, The American Soldier: Adjustment during Army Life, vol 1. Science Editions, John Wiley and Sons Inc., New York, 1965, pp 459,438

55. Camfield, Thomas M, "'Will to Win' - The U.S. Army Morale Program of World War I', Military Affairs, vol 61, no 3, Okt 1977, p 126

56. Pakenham, op cit, p 278

57. Du Preez, op cit, $p$ p 60

58. Mc Nulty, J.T., "Morale and the Nuclear Age", The Irish Defence Journal, vol 27, no 6, Jun 1967, p 328

59. Baynes, op cit, p 100; Hart, op cit, p 38

60. Baynes, op cit, p 108

61. Stouffer, Samuel A., The American Soldier: Combat and its Aftermath, vol II. Science Editions, John Wiley and Sons, Inc., New York, 1965, p 169

62. Bartlett, op cit, $p 159$

63. Moran, op cit, p 170

64. National Research Council, op cit, p 286; Mac Curdy, op cit, p 79

65. National Research Council, op cit, p 287; Patten, Thomas H., "team Building. Part I Designing and Intervention." Personnel, Jan - Feb 1979, pp 11, 12

66. Stouffer, The American Soldier, vol I, op cit, p 41

67. Fowler, John G., "Combat Cohesion in Vietnam", Military Review, col 59, no 12, Des 1979, p 25

68. Barker, C.N., "A Regimental Officer's Analysis of Morale", Journal of the Royal United Service Institution, vol 107, no 628, Nov 1962, p 328; Copeland, op cit, $p 13$ 